\title{
Authentic recreation: living history and leisure
}

\author{
Lain Hart* \\ Bethnal Green, London
}

\begin{abstract}
This essay considers a postmodern interpretation of the concept of authenticity and a criticism of that interpretation advanced from an ethnographic perspective. The author shows how these theoretical issues arise at American Civil War reenactments by describing the ways by which the reenactment community establishes authentic appearances at Civil War performances. The essay then considers the commercial activity conducted at Civil War events, and concludes by speaking to the question, posed by the postmodernists, as to whether it is possible to represent the past authentically.
\end{abstract}

Key words: authenticity; living history; performance studies; mimmimesis; American Civil War reenactment

\section{Introduction}

On the border of modern-day Algeria and Morocco, there is a town inhabited by a Berber tribe called Zouaoua. In the early nineteenth-century the Berbers from this region impressed Europeans with their impetuous battlefield courage and soon their reputation spread to the United States, where they were known as Zouaves. As abolitionist and secessionist tensions escalated in the run-up to the Civil War, a multitude of volunteer militia companies on both sides of the Mason-Dixon Line declared their readiness. Hundreds declared themselves 'Zouaves'.

Before the war American Zouave militias held nation-wide military drill competitions, while also undertaking an unofficial competition for the most dashing colonial North Africanstyle uniform. For them, perhaps as much as it is for Civil War reenactors today, war was all about looking good. Northern and Southern Zouaves assembled for actual combat at the Civil War's first major land battle, the Battle of First Manassas in 1861. More regiments from North and South turned up to add to the confusion, resplendent in kilts and busbies and bearskin hats. When the battle was joined Civil War soldiers misidentified miscellaneous regimental flags and uniforms so routinely that at Manassas 'friendly fire' casualties rivaled the numbers killed by enemies.

Watching over this slaughter was a crowd of Washingtonians, civilians who had rushed from the nation's capital to catch a glimpse of the Confederacy's prompt defeat. They arrived on trains and carriages, with parasols and carpet bags and picnic baskets in hand.

The Confederacy, however, lived on past that first battle in 1861. Confederate forces turned the mêlée at First Manassas into a Union rout; the spectating civilians streamed in a mad panic from Virginia back to the safety of Washington, DC. For two years afterwards, in fact, the Union seemed doomed, and it was not until a town called Gettysburg played host to one of the largest land battles on the American continent that the Northern states, and the abolitionist cause, seemed to ascend over the pro-slave rebels.

On a sun-drenched, muggy July day in 2006, I attended the annual reenactment of the Battle of Gettysburg. Having driven for hours deep into the Pennsylvania countryside, I gave my ticket at the gate and took a seat in the grand-stands ${ }^{1}$ (Fig 1) for a late-afternoon performance on the second day of the three-day event. A licensed National Park guide set up the scene over a loudspeaker: He sketched the arrangement of the armies on the second day of the historic 


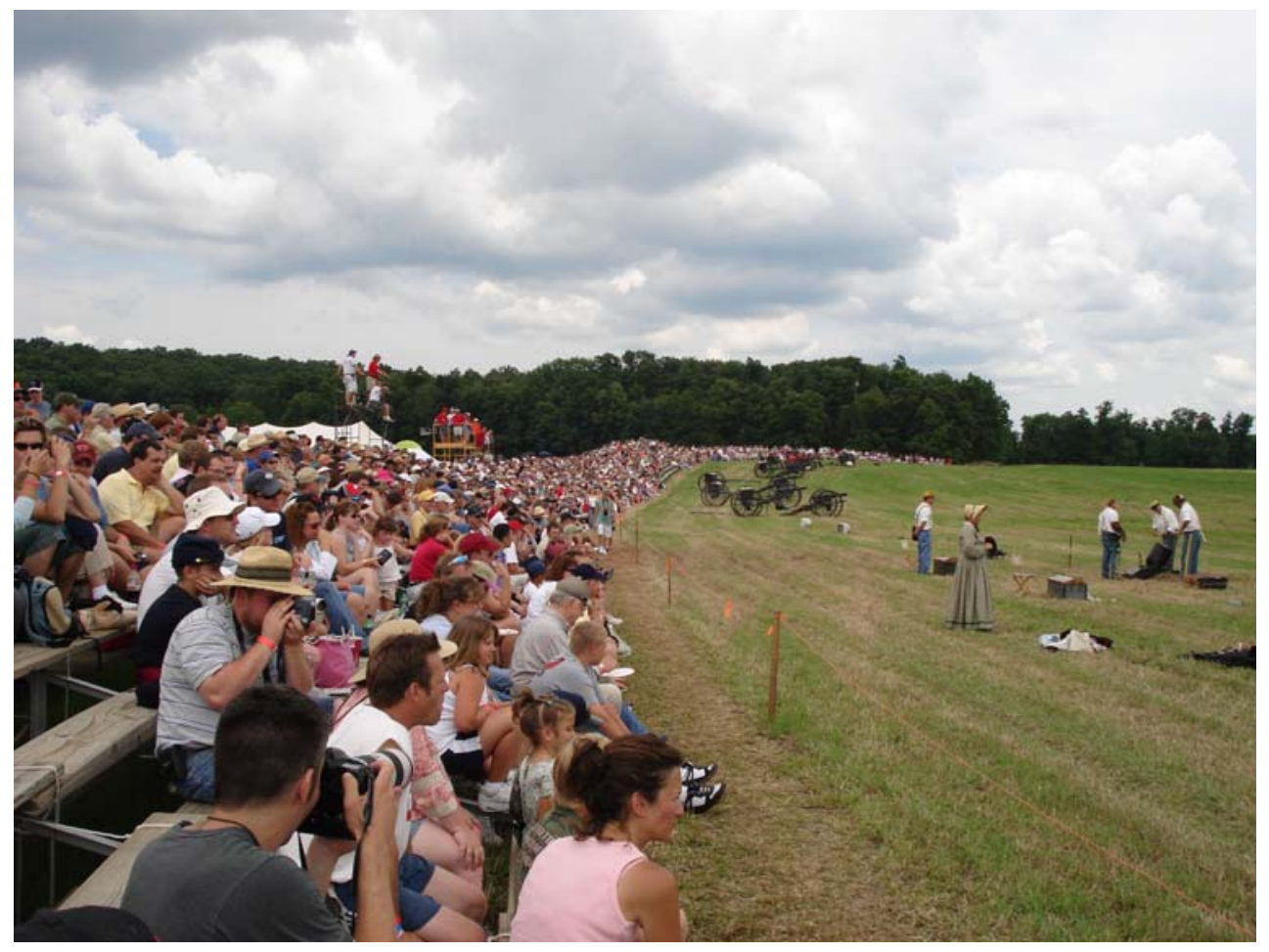

Fig. 1 The grandstands

battle, noting the positions of important officers like the Confederate General Robert E. Lee, and then he described how the Union troops were safely emplaced on the high ground.

As he spoke reproduction cannons fired blanks, and ground-launched fireworks simulated the jellyfish-shaped air-burst of shots fused for an overhead detonation. The guide explained the difference between these and canister shot and solid shot, and from this technical lesson on ordinance he segued to a discussion of General Lee's plan: To win, his troops would have to defeat the Union artillery that was deployed in a commanding position along the ridge. In order to push through the enemy infantry and seize or destroy the lofty Federal cannon, Lee ordered an all-out attack.

'Think of the ridge here as Cemetery Ridge', said the guide, naming a battlefield landmark that was actually over a mile away. 'And the road, think of it as the Emmitsburg Road', he added, indicating a dirt track cresting the far hill, where a corps of Confederate reenactors could be seen gathering into a formation. 'Or if you're really familiar with the battle', he said, 'think of the Trossel Thicket'.

From the grand-stands, we could see US flags poking up over 'Cemetery Ridge' from the opposite side of the rise. A body of blue-clad troops soon came over the ridge and formed up their ranks, recreating the First Minnesota Regiment's accidental lurch onto open ground. Mistakenly deployed a little too far forward of the main Union line, near an abandoned farmstead that belonged to the Trossel family, the First Minnesota faced the brunt of the on-coming rebel attack.

The artillery fire ceased as the blue-clad Union reenactors and a motley grey column poured into each other across the football-field-sized space. Their ranks crackling with synchronized volleys, the acrid smell of burning black powder swept over the reenactors in a thick white cloud, and wafted towards the stands. Backtracking up the ridge to the audience's left, the Union force seemed to be in retreat, until a reenactor impersonating General Hancock galloped over the hill. Just as the original general was said to have done, he encouraged the 
Unionists to stand fast, assuring them that reinforcements were on their way. Having stalled the Confederates for long enough, Union help finally did arrive, streaming down from behind the ridge onto the rebel flanks (Fig. 2).

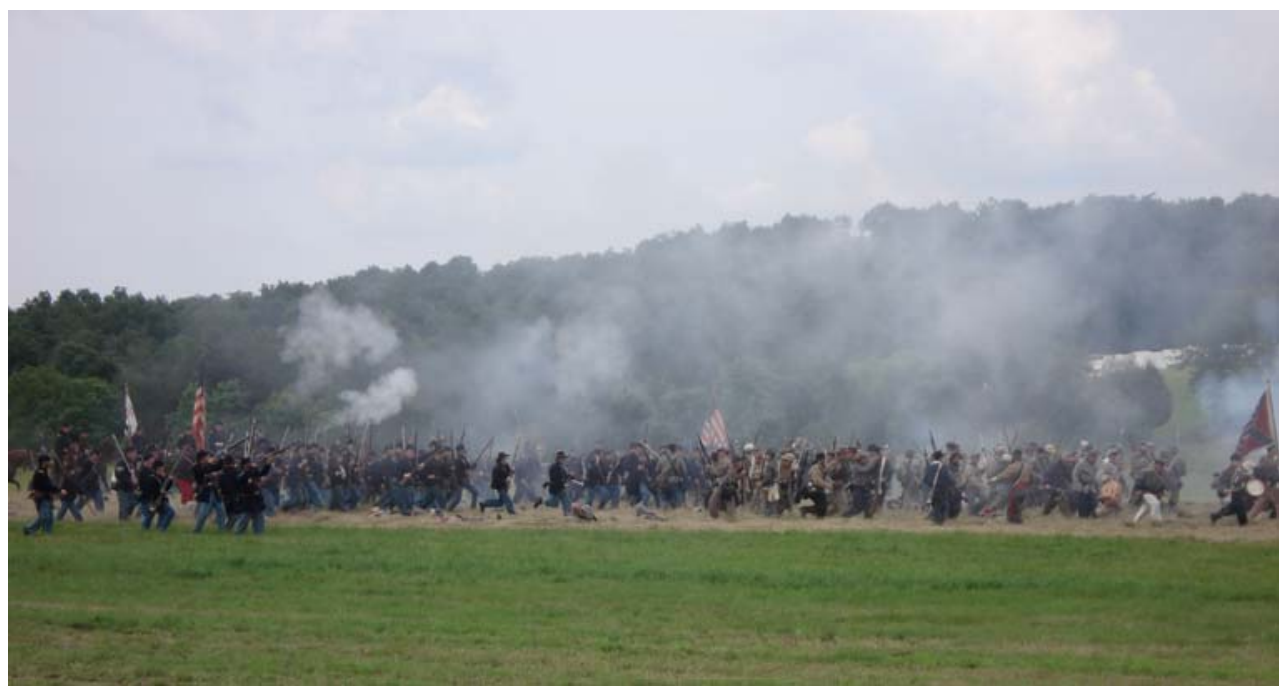

Fig. 2 Onto the Rebel flanks

The rebel reenactors routed. Then they paused with a bugle and drums corps mid-field at a low stone wall, which had been built especially for the event in order to mark the 'fifty-yard line'. Union and Confederate reenactors uncovered their heads to the funereal notes of 'Taps'. Spectators and participants alike closed the performance by observing a respectful silence for the original battle's dead.

A Civil War reenactment is in part a memorial service. It is partly, too, a leisure activity. Furthermore most reenactors assert an educational import to the performance, and to develop their roles many pursue archival research with a rare dedication. On the other hand Civil War reenactments are increasingly commercial spectacles, with as many as fifty thousand Americans routinely gathering at (or near) historical Civil War battlefields in order to stage performances that purport to recreate the conflict, while hundreds of thousands more spectate (Hadden 1996: 5).

I will show how theoretical issues of authenticity arise as practical problems in the Civil War reenactment community by presenting my own observations from the 2006 Gettysburg reenactment and by relying on a number of texts produced by participant-observers. In particular I will refer to Robert Lee Hodge, who was made famous by Tony Horwitz's 1996 book, Confederates in the Attic, and who served as a kind of Virgil to the author on his journey through a Confederate Valhalla. From these sources I will argue that 'Living History' performances require an interpretive apparatus that takes genuine history as its authority, while remaining external to both participants and tourists, who may well be unaware of how closely their own involvement approximates genuine historical events.

\section{Theory}

Reenactors have staged recreations of Civil War battles almost since the conclusion of the war itself. Union veterans, as a group called the 'Grand Army of the Republic', started holding battlefield reunions in the 1870s. They camped in canvas tents and publicly performed the most famous moments of the conflict, sometimes fighting National Guardsmen who impersonated the Confederates, but sometimes re-fighting the Southern veterans themselves (Kauffman 2006: 125-26). Afterwards the Army War College and the Virginia Military Institute kept the 
tradition alive from the 1920 s to the 1960 s by sending modern-day soldiers into reenacted battles in order to instruct new generations of army officer candidates in Civil War tactics (Hadden 1996: 3).

An 'authentic' reenactment, in that context, depended on nothing more than the location of participants. The object, to demonstrate the strategic thinking of the Civil War commanders involved and the movements of their troops, demanded nothing of the participants in terms of appearance or general behaviour. Civil War reenacting since the 1970s is a very different kind of performance; while the reenactment locations may not, in fact, be those of the actual battlefield, reenactors now pursue an individuated experience that depends on the whole group's combined efforts to effect an 1860s appearance. Some participants style themselves amateur experts in Civil War lore, eschewing the term 'reenactor' in preference for the title of 'Living Historians'.

Just like tourists on a summer holiday, who seek the 'authentic' beach experience in the most depopulated stretch of sea-coast, and who revel in the 'authentic' ambience of an undiscovered locale, Civil War reenactors are, in the analysis given by Richard Handler and William Saxton, deluded. The appearance of authenticity, for these tourists, emerges not from any fidelity to an authoritative original, but rather from present-day 'individual and institutional attempts to systematize the manufacturing, marketing, appropriation, and accommodation of novelty and difference' (Handler and Saxton 1988: 258). By way of their emphasis on the constructed nature of authenticity, as found in history-themed tourism, Handler and Saxton do make important points regarding the commercialization of heritage, but I am inclined to agree with Edward Bruner's criticism of their argument. He faulted Handler and Saxton for their cynicism, and for their apparent contempt of the reenactors themselves; he accused them of politicizing an investigation into the reality of authenticity in order to further a critique of modernity in general, and modern Americans in particular.

Bruner defended 'Living History' as an educational enterprise, citing the ethnographic tradition of James Frazer, Victor Turner, and Michael Taussig. Often dealing with the social dramas of societies at the periphery of modernity, this tradition tends to emphasize the ways in which participants ritually perform their own social identities, especially through the representation of resistance and alterity. According to this point of view, as mimesis; that is, as a ritualistic performance providing meaning in the present by digesting the power of the original events, 'Living History' can be 'a good way to learn about the past' (Bruner 1994: 411).

Handler and Saxton, on the other hand, treated Civil War reenactment as a distortion of the past. They argued in favour of the postmodern perspectives of Dean MacCannell, Umberto Eco, and Jean Baudrillard. Handler and Saxton asserted first that 'modern individualism makes of the human person a self-contained monad, a creature who finds ultimate reality or meaning within him or herself ' (Handler and Saxton 1988: 247). This modern individualism is a 'possessive individualism', whereby 'individuals attempt to realize themselves by purchasing experiences (education, travel, entertainment, fitness)', and among all these opportunities for self-improvement through leisure 'history is recognized as an authoritative reality, one capable of generating authentic experiences' (Handler and Saxton 1988: 248). Reenacting proffers the 'hyperreality' of Baudrillard's simulacrum, and in an electronic, capitalist system that substitutes 'signs of the real for the real itself' (1984: 254), individuals seek the purity of a real experience in heritage-themed tourism, but forever in vain.

Gettysburg is the most visited battlefield in the United States, and Civil War historian James McPherson speculated that more tourists flock to Gettysburg than all other battlefields combined. ${ }^{2}$ In fact ever since the eponymous southern Pennsylvania hamlet was transformed into a landmark by the attentions of Civil War armies, its local economy has depended almost entirely on heritage-themed tourism. For instance, shortly after the Civil War, a local consortium built a trolley line over the southern part of the battlefield, and another entrepreneur erected a 307-foot tall observation tower. In the post-World War II period of vast new highways and air conditioned cars, scenic by-ways wound round the battlefield along instructive plaques of text. Later the battlefield began offering cassette tapes with recorded descriptions of the battle for tourists to play on their car stereos as they rambled over the sacred acres.

Well-attended reenactments in the 1980s prompted the Gettysburg National Military Park administration to scale back such events in order to protect the appearance of the 
landscape. By then, too, the costs of preservation and maintenance compelled park employees to rely less on the Federal government and more on fundraising. While Gettysburg's annual reenactment moved to privately owned land to acquire investors and a business model, Civil War reenactors have at the same time taken the lead in a drive to 'save' America's national battlefield parks, buy back land and return the landscape to its 'original' appearance. In 2000 , for instance, the soaring observation tower at Gettysburg was demolished. After negotiating compensation, the lawyer for the owner of the old tower quipped, 'If we want to be complete, we could restore the stench of rotting flesh'. ${ }^{3}$

Bruner argued that, like the activists who demanded the destruction of the tower, postmodernists define authenticity too narrowly. 'My aim [in visiting the New Salem Living History Village] was to understand the different meanings of authenticity as employed in social practice rather than to accept at face value the usually unexamined dichotomy between what is and is not authentic [emphasis in original]'. What Bruner found was four definitions or contexts for the term, 'based on verisimilitude, genuineness, originality, and authority' (Bruner 1994: 401).

Since a reenactment is an acknowledged reproduction, authenticity in the sense of originality, as the postmodernists use the word, is actually an irrelevance. Authenticity, as the participants themselves use it, more often denotes an approximation of the original. Bruner (1994) made plain the difference between verisimilitude and genuineness:

The houses at the 1990s New Salem represent the original 1830s houses, thus they are weathered to look old so that they will be more credible, as the original houses existed 160 years ago. The 1830s houses, however, actually looked much newer, as the village of New Salem was founded in 1829 and abandoned by 1839 , a period of only ten years. The 1830 s houses were not occupied long enough to look aged, hence the 1990s houses at New Salem appear older than the originals. This example shows that there is a tension between the first and second meanings of authenticity. To the degree that the houses look old and weathered, they are more credible to the visitors [verisimilitude] but are a less accurate reproduction of the 1830s [genuineness] (Bruner: 1994: 402).

Finally, to understand what Bruner means by 'authority', it is important to point out that although Bruner was speaking directly to Handler and Saxton's essay on reenacting, his own observations were of New Salem, a state-sponsored Lincoln-themed Living History enterprise in Illinois. Authority, for Bruner, referred to the apparatus of management and funding that aligns itself either with a genuine approximation of the original, or with the appetites of New Salem tourists for verisimilitude. In Civil War reenactments, especially those conducted under the auspices of the National Park Service, the documented history of the Civil War is taken to be the 'authority' in all matters of representation. Opportunities for leisure therefore overlap the conscious evocation of nineteenth-century life, sometimes even spontaneously and without much apparent intent, while on the other hand asserting fidelity to the written record may interfere with other reenactors' recreational goals and divide the group.

\section{Authority and authenticity}

In 1989 Civil War buff Lauren Cook bound her breasts under a Confederate uniform and fell into formation with other participants at a reenactment of the Battle of Antietam. Cook realized, however, in the middle of the treeless expanse, that she needed to use the restroom. After escaping to the privacy of a port-a-john, she returned to her unit. Another reenactor had already reported to a National Park Ranger that he spotted a Confederate soldier leaving the ladies' restrooms. When he found Cook and finally identified her as a woman, the Ranger demanded that she leave the reenactment immediately.

In the process of filing a sexual discrimination suit against the National Park Service, Lauren Cook researched Civil War fighting women extensively. She won her case in 1993 by proving that not only did hundreds of women serve in uniform on both sides during the Civil War, eight of those women fought at Antietam-where five were killed. Cook's collaboration with Civil War scholars also produced in 2002 They Fought Like Demons: Women Soldiers in the Civil 
War. The first authoritative text on women in Civil War combat, in it Cook and her co-author revealed that 'although politicians and pundits were often critical, male soldiers usually accepted their female comrades once they were unmasked'. ${ }^{4}$

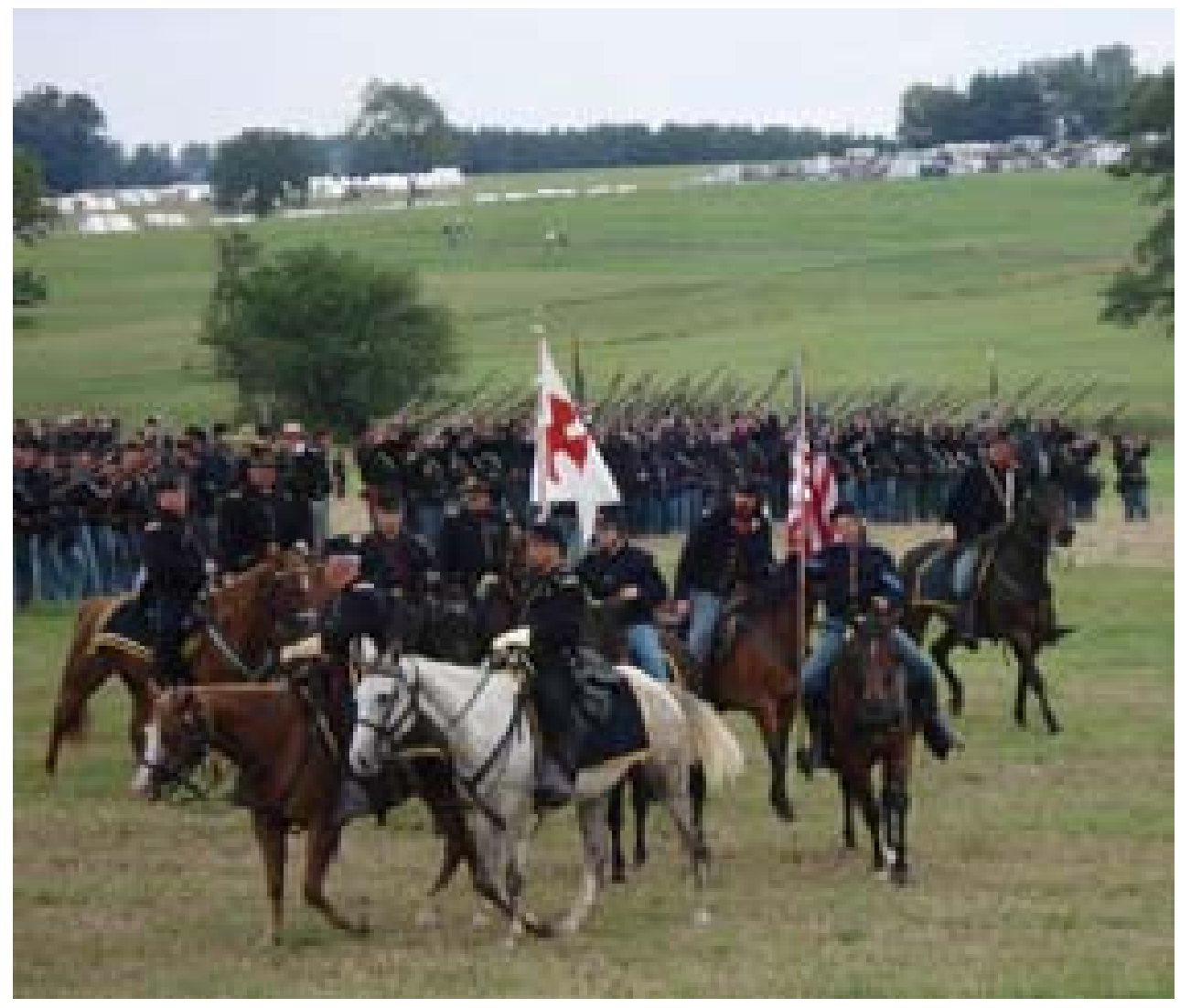

Fig. 3 Gettysburg re-enactment

True to the Civil War soldiers they emulate, many modern-day male reenactors in the aftermath of the Cook case accepted women into the ranks. Although the Antietam judgment applies only to events on public land, a large number of reenactors can be easily recognized as women, even at those events that, like Gettysburg, are now held on private land (Fig. 3). The fact that female horseback riding hobbyists and professionals comprise $80 \%$ of the riding population in the United States makes women's battlefield participation convenient to the reenactment organizers, ${ }^{5}$ who are rarely capable of bringing together enough reenactors, especially cavalrymen, to even approximate the number of troops indicated by the historical sources.

Despite the practical opportunities that female reenactors bring in their numbers-and their horses-some event organizers and reenactor group officers continue to uphold a total ban on women in their fighting ranks. They will send home a woman who can be recognized as such from the spectator seating, or at fifteen paces, or six feet, or from some other arbitrary distance or even up close. The logic is that in order to be authentic, a woman may only join the ranks if she meets the Civil War-era criteria-that is, that she disguise herself and remain undetected.

In 1991, under the pen-name 'Jonah Begone', a veteran reenactor bemoaned the consequences of the Cook case in an essay published in his regiment's newsletter as 'Victor/ Victorian!' He made it clear that his own opposition to women in the ranks stemmed not from any universally applicable standard of authenticity, but rather from a contempt for 'political 
correctness' and his own concern over the emotional cohesion of a male-dominated leisure world. 'I will be the first to admit that reenacting is at heart a silly pastime... [W] hat we're really doing is replicating the dirt clod vacant lot battles of our youth... But girls weren't tolerated in any of the vacant lots I played in back then and shouldn't be now!' 6

Rory Turner reported that, according to his experience as a participant-observer in the mid-1990s, Civil War reenacting appeared to be for men and women both a dainty, decorous, and mostly sartorial spectacle of nostalgia. Large reenactments, for instance, conclude with a 'Blue and Gray Ball', and one female participant confessed to Turner that she was entranced by the 'old way of life' and the 'lace and fringe and gaudy things' (Turner 1990: 131). Many of these women prefer not to take up a replica rifle, but to play-up their femininity, donning the hoop-skirts and stiff corsets of yore. Another female civilian reenactor told the sociologist Amanda Kennedy: 'Why I like doing Civil War reenacting is the clothing. I wouldn't do a reenactment from a period when the clothes were... ugly' (Kennedy 2004: 26).

Off the field of combat women take the lead, as they did during the Civil War, in goodwill social organizations. The Women's Central Association of Relief, the US Sanitary Commission, the Ladies Loyalty League, and the Soldier's Aid Society have all been resurrected by female civilian reenactors. Just as in the mid-nineteenth-century, women's roles at reenactments are parturient; they emerge in the process of dismantling a foregoing classification. For example an online list of suggested female roles included both 'feminist' and 'agitator', ${ }^{7}$ and one woman told Kennedy that she 'only became more interested [in reenacting] when I found out that this was the beginning of the women's suffrage movement that eventually gave women the right to vote, and even to serve [in] the military' (Kennedy 2004: 28).

Female participation in non-combatant roles is, in a way, a more powerful presence at a reenactment than that of disguised women-warriors like Cook, since the non-combatants reclassify the ritual space of the performance. For instance Dr. Rowe is a female reenactor I spoke

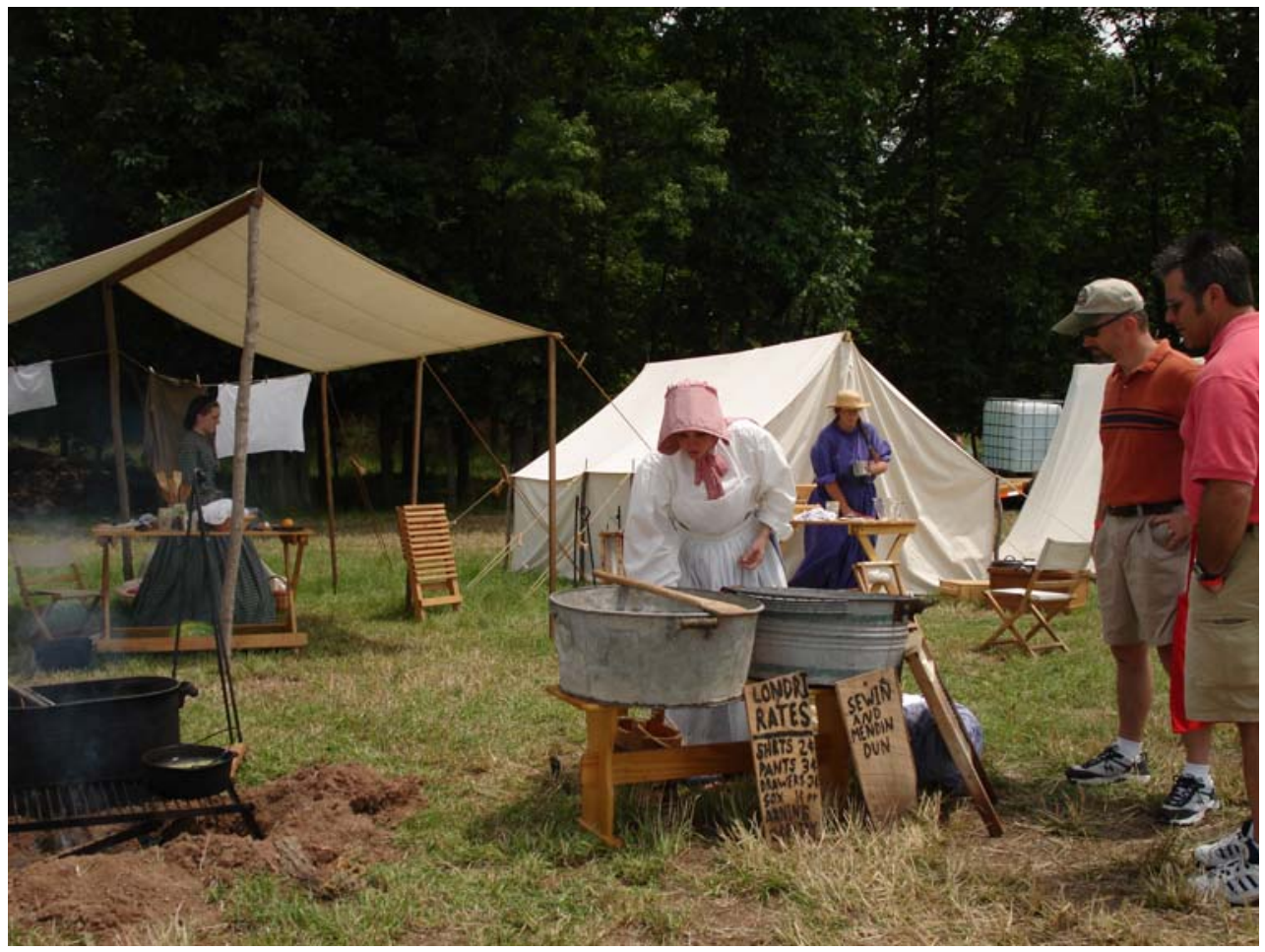

Fig. 4 Female re-enactors display the reach of war into the wider society 


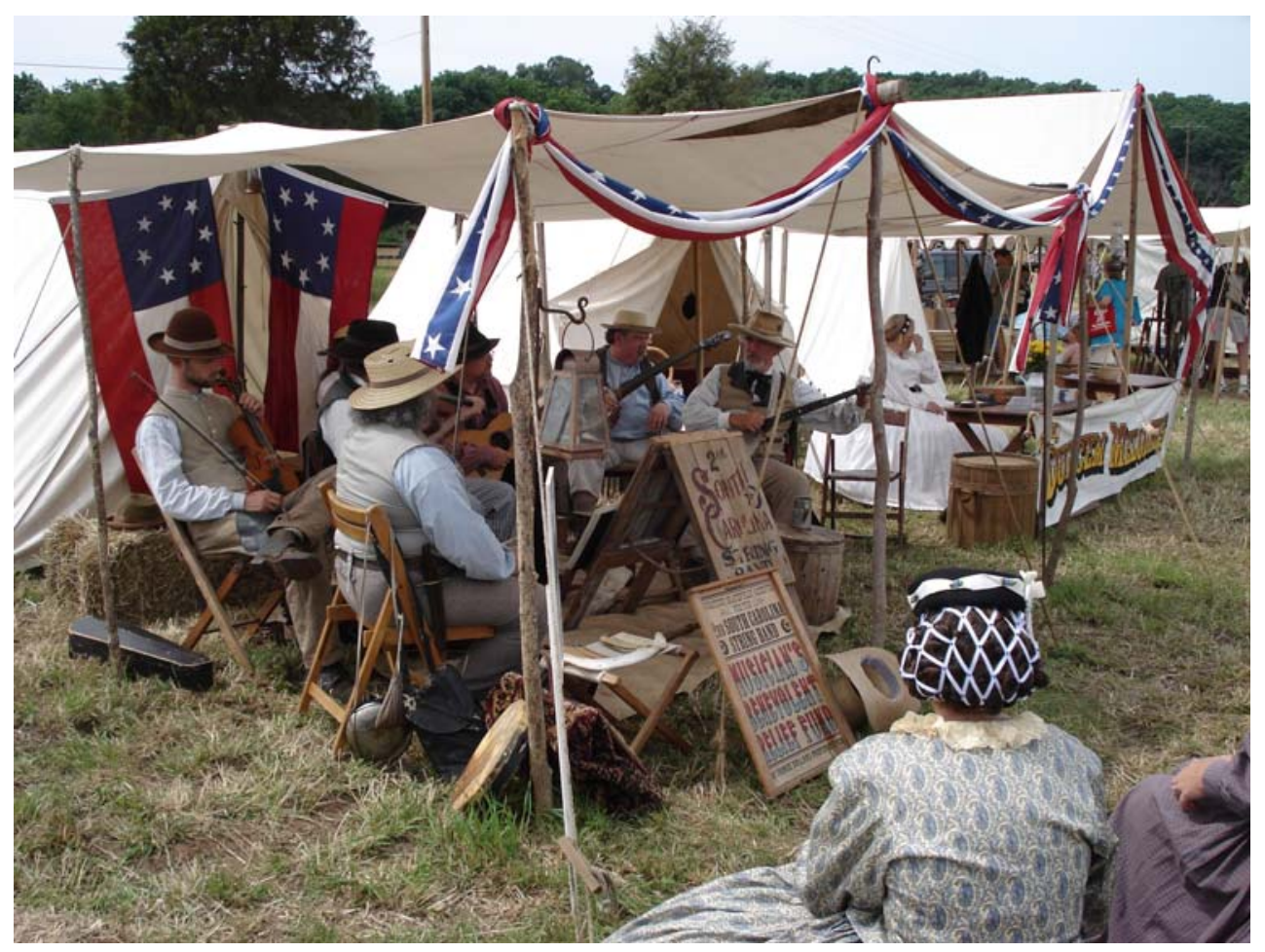

Fig. 5 Many musicians, male and female, participate in Civil War reenactments.

with who first started reenacting in order to be with her husband and son, but as a medical doctor she became more involved through her regiment's period field hospital display. 'Most of the time people are enamored of the blood and guts', she said. 'We're not as interested in the blood and guts. We're trying to emphasize the socio-economic aspect, the way of life that shaped medicine at the time'. Female reenactors at Gettysburg, 2006, also gave talks on period fashions, 1860s home life, and the activities of female spies during the Civil War. At reenactments Dr. Rowe and these other participants create a zone around the essential 'dirt clod battle' to display the reach of war into wider society (Fig. 4).

Female reenactors have been so successful in this that men, too, regularly join them on the sidelines as war correspondents, preachers, teamsters, gamblers, railroad workers, slave catchers, telegraph operators, con men, or local farmers (Hadden 1996: 94). At the Battle of New Market, one male participant 'a cartographer in real life as well as in the reenactment, demonstrated his tools and maps. For him, reenacting was a way to perform his interest in history, and to use his occupational skills in a particularly satisfying way' (Turner 1990: 128). This is equally true of the many musicians, male and female, who participate in Civil War reenactments (Fig. 5).

In another case state authority adjusted the protocols of the performance by way of the court system when a reenactor sued event organizers for the burns he suffered at a Gettysburg reenactment (Dunning 2002:66). Precise conventions now govern not only the activity around artillery pieces but also hand-to-hand combat (Hadden 1996: 110). Furthermore reenacting recruits are now taught by experienced reenactors to aim high when they fire their weapons.

Besides directing the muzzle-blast in a safer direction, this policy also helps avoid the arguments that arise over who should 'take a hit'. Reenactors are generally reluctant to play dead. 'Nobody wants to drive three hours and spend the day lying on cowpies', said one reenactor (Horwitz 1996: 133). Participants 'die' or feign wounds if they get tired, or if they are 
ordered to do so by an officer. ${ }^{8}$ Some reenactors smear fake blood on themselves, but this is very much looked down upon by other reenactors.

In choosing exactly how to provision his or her Civil Warera alter-ego-to use fake blood or not to use fake blood, for instancethe reenactor establishes relationships with other hobbyists. While personality, genealogy, and to some extent ideology may determine group membership, affiliating with the various reenacting groups is primarily a matter of appearance. Or, in the parlance of reenactor groups, it is a matter of one's 'impression'.

I do what you call the history-heavy side of the hobby', declared Private Brandon (Fig. 6). Far from the main Confederate encampment, Brandon sat on a patch of grass with his minimal gear at the 2006 Gettysburg reenactment. His surroundings doubled as both personal camping equipment and as a kind of museum case, for which Brandon was himself the interpreter. With any interested

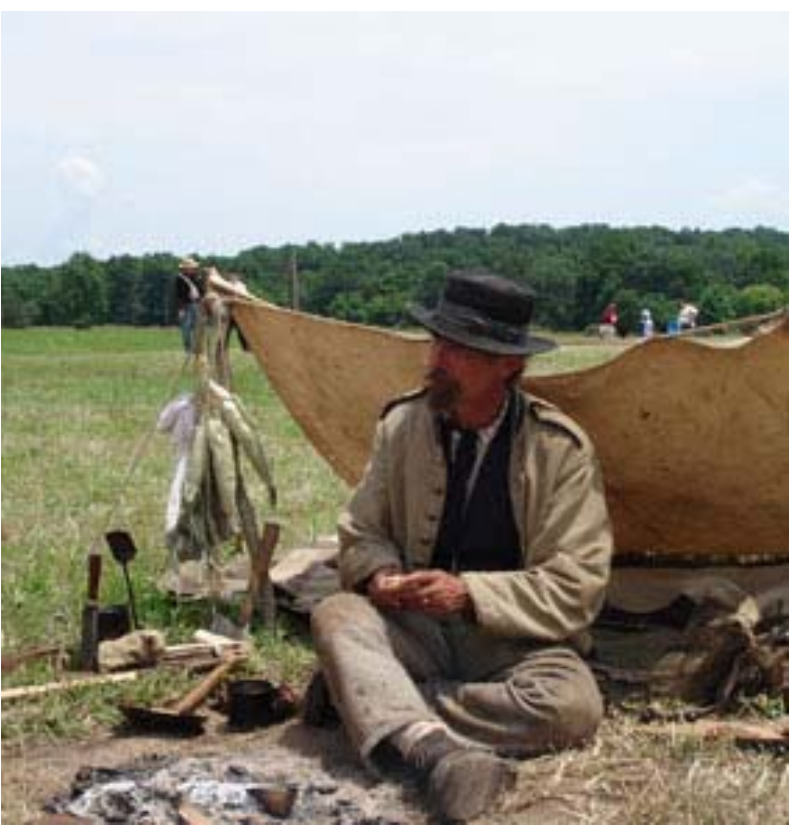

Fig. 6 Private Brandon onlooker Brandon happily discussed Civil War footwear, or how to use a bayonet and a canteen as a frying pan, or any other aspect of a Confederate soldier's experience of the Civil War. 'I live it', he said. 'I carry all the equipment... [and] I woulda frozen to death on some nights if it weren't for the warmth of my companions'.

'You live like this all weekend?' asked one tourist.

'I live like this about every weekend', answered Brandon.

He was not speaking in-character, as if an actual Civil War soldier; despite the precisely cultivated authenticity of his appearance, Brandon did not affect an historical persona, but spoke instead from a twenty-first-century perspective, joking with tourists about hiding away an iPod. He also pointed out that his trousers had been hand-sewn by his real-life son, also a reenactor. In fact Private Brandon claimed to be a 'heavy traveler' compared to his son. 'A lot of these young kids they'll bring this along [he picked up a thin oil blanket] and wrap up in that and sleep and that's it'.

This kind of reenactor self-consciously stands apart from the rest of the group (Cavin et al. 2005: 2). 'Hardcores', 'authentic campaigners', 'campaigners', or 'authentics' are all terms used to describe this type of hobbyist. Fearless about taking on genuine Civil War experiences like rugged camping, they are also meticulous about recreating the appearance of a Civil War soldier. Authentics like Brandon consult photographs and historical documents for issues as seemingly minor as the sheen of a brass button.

The term used to describe their opposite is 'farb' -a derogatory term for which there is no certain etymology. 'The tension between these two types threatens to fracture the reenactor movement. Some hardcore units will not participate in events that are expected to have too large a 'farb quotient" (Farmer 2005: 59).

'If I had my company here', Private Brandon told me, 'we'd have our mess and we'd be sharing everything, sharing the same food, sharing the same utensils'. His 'company', though, 


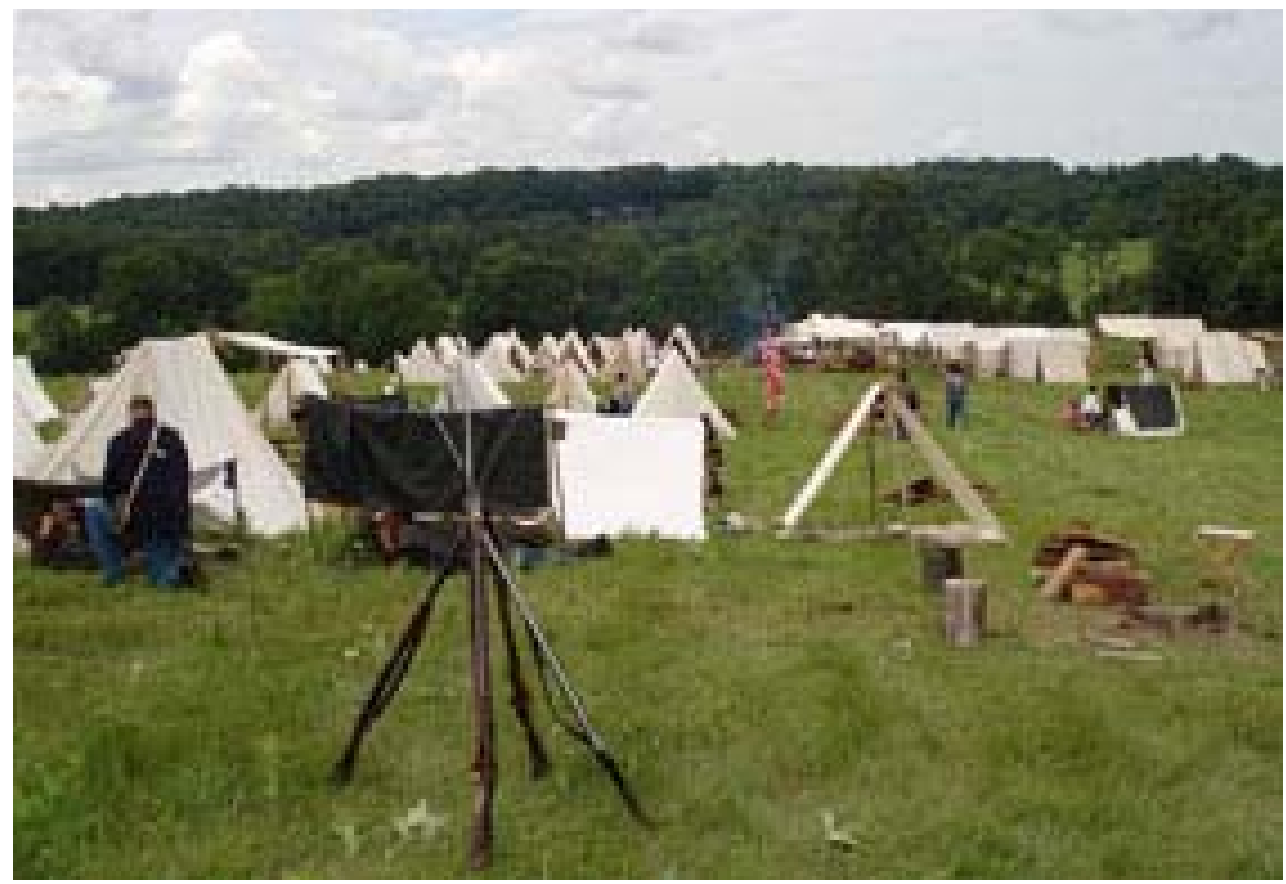

Fig. 7 'Living History Village'

long ago began a boycott of the Gettysburg event. 'The guy who organizes this is a friend of mine', Brandon explained. He did not take part in any of the battles and spent the whole weekend in the section of the reenactment defined as a 'Living History Village', choosing not to join the soldiers' encampments (Figs. 7 \& 8). 'This is family camping', he said.

'Family camping' and 'mainstream' are terms that are, for authentics or hardcores like Brandon, more or less interchangeable with 'farb'. Yet the great majority of Civil War reenactors

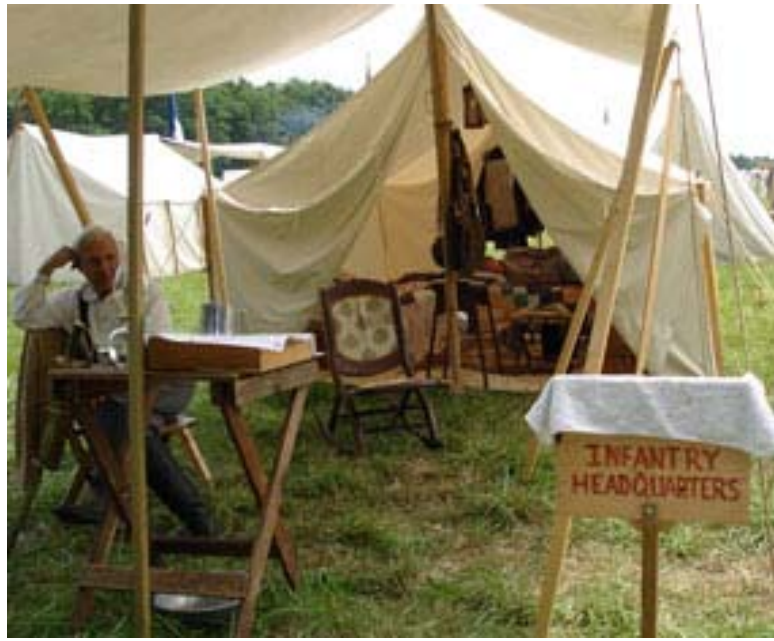

Fig. 8 'Living History Village' do not identify themselves as hardcores (Dunning 2002: 67), and mainstream events draw far more participants and spectators. Authentic campaigner types tend toward smaller, invitation-only events. They prefer long marches through the countryside in authentically minimal gear to reenacted battles. Many, like Brandon, give presentations at historic sites and schools under the auspices of the National Park Service.

Whether their membership is interested primarily in leisure or adamant about authenticity, reenactor groups together reproduce the overall structure of armies in the 1860s. That is, reenactors observe a chain of 
command and practice a regimental system that derives, wherever possible, from the actual unit identifications of Civil War troops. For instance the 'Stonewall Brigade', which was named for its commander, Confederate General Thomas 'Stonewall' Jackson, was an historic army unit that fought from 1861 to 1864 and comprised the Second, Fourth, Fifth, 27th, and 33rd Virginia Infantry regiments. Each of these regiments now has a modern-day counterpart, even though each is much diminished in numbers. ${ }^{9}$

By federalizing under brigade-level and battalion-level commands, the reenactor communities' mimicry of historical military hierarchy has given rise to umbrella organizations that establish cross-regimental criteria. The Stonewall Brigade is one such group, and the Mifflin Guard is arguably the most esteemed of all super-regimental societies (Dunning 2002: 66). Alliances, expulsions, and schisms within these organizations all mark a rather different sense of competition than that their historic forebears would have ever had the luxury to practice. Instead of the bloody honors of combat experiences, the reenactor units of today acquire reputation by their adherence-or indifference-to authenticity. It was as a result of just such a schism that Robert Lee Hodge and a handful of hardcore Civil War enthusiasts broke away from their own 'farby' battalions and formed the 'Southern Guard'. As Brandon told me: 'Hardcore units will tell you what they want you to have, what they'll tolerate you having, and what you absolutely cannot have'. Cell phones, coolers full of beer and plastic-wrapped snacks, as well as cigarettes and small children, were all very much in evidence at the Gettysburg, 2006, encampment-but these things are all strictly forbidden among authentics.

As much as Hodge, Private Brandon, and other authentics look down on family camping farbs, the animosity goes both ways. 'Stitch nazis', 'thread-counters', and 'button pissers' -a reference to a technique for giving brass buttons a more authentic patina-are all derogatory terms used to describe the so-called hardcores. 'In their quest for authenticity', wrote Hadden (1996), 'many [hardcores] have been openly rude and abusive to those who do not meet their standards of authenticity... This is a bad trend that harms the whole hobby and needs to be stopped... This type of behavior is boorish, and nineteenth-century manners would not have permitted it. Certainly 1860s standards of hospitality and courtesy are as important to authenticity as clothing conventions' (Hadden 1996: 136).

While authentic campaigners may deserve their reputation for elitism, Hodge himself seemed not so much elitist as evangelist. It takes just one reenactor, he said, 'to turn their whole unit around' (Horwitz 1996: 140). In fact during a reenactment of the Battle of the Wilderness, Hodge met up with Horwitz to slip on old-fashioned red 'Ambulance Corps' arm-bands and join in as civilians. With a quantity of gin in period container, they set out to marry nineteenth-century battlefield medicine to twentieth-century reenactor proselytizing.

Combing the field of simulated carnage, Hodge appraised the different units and individual reenactors: 'Look at that guy with the derby hat. Ridiculous. It's 1880s Butch Cassidy stuff... See the big officer over there? Great uniform, but the weight's way out of line. And who's the guy behind him with the red pants? He looks like a circus clown... Ouch, way too much red trim on those artillery uniforms. They look like Shriners... Poor cut. Wrong trouser color. And way too much blubber. The whole unit needs liposuction'. Pointing out a Confederate Captain, Hodge opined, 'A real Confederate would eventually have cut that hair to keep the lice under control. And what's with the hat? It's all wrong- Boer War maybe, not this one'. Finally, Hodge spotted a young rebel who was wearing his bedroll the right way. The boy pretended to take a hit, thrashing around and clawing through his coat at an imaginary hole in his chest.

Rob Hodge rushed over to the rebel, Horwitz behind him. While Horwitz mimed checking a pulse Hodge cradled the boy's head in his lap and doused his mouth with gin. 'Great hit', Hodge said. 'I liked the bouncing around. Looked like a nerve wound. You ever heard of the Southern Guard?' (Horwitz 1996: 141).

Reenactor groups bring along to each event a 'fact book' that gives the historical background on the regiment, their recorded movements, appearance and lore. While it establishes an organizational architecture for dealing with interpretations of authenticity, the regimental format is just as important in that it provides an opportunity for reenactors to represent the variegated appearances of different units. For instance Civil War regiments carried their own flags and sometimes they had a musical section or a mascot. Especially at the start of the war, they may have worn an idiosyncratic uniform. 
In some cases, however, an authentic regimental impression is a matter of skin-colour: The 54th Massachusetts, the regiment of United States Colored Troops (USCT) made famous by the movie Glory, today exists in Charleston, South Carolina as the 54th Massachusetts Volunteer Infantry, Company I, and Company B, based in Washington, DC. ${ }^{10}$ Subdivided into companies, the reenactors' regimental format also establishes an apparatus of local cohesion, like the basic 'Chapter' or 'Lodge' of an ordinary social organization.

Yet Young (1999) argued that, far from being an innocuous hobby for history buffs, anyone who dons a Confederate uniform 'cannot escape the associations' between the costume and 'a history of determined efforts against black freedom' (Young 1999: 301). Essays and books published as American Studies have in large part treated Civil War reenactment groups as politically reactionary heritage cults. Farmer (2005) observed the audience cheering victorious Confederate reenactors at an event in South Carolina, leading him to propose that the main purpose of the performance appeared to be 'to celebrate a symbolic blow against the hated enemy of their ancestors and, perhaps, against what they see as that enemy's modern counterparts: the champions of political correctness' (Farmer 2005: 51). Even when Southern sympathies are not so much in the foreground, Cushman (1999) and Kauffman (2006) faulted Civil War reenactment for approaching pro-slave and abolitionist ideologies with an attitude of moral indifference.

In fact reenacting draws on a tradition of Civil War remembrance that dates from the end of the war itself, when new themes of national identity reconciled to one another white Americans of all regions (see Lawson 2002). Jim Crow laws, Manifest Destiny, imperial adventures overseas, and the wisteria-scented romances of plantation society all nurtured the idea of a shared white triumph at the end of the nineteenth-century. Their emancipation betrayed, some black Americans who fought for the Union felt compelled to keep their record of service quietly to themselves for the rest of their lives, for fear of reprisals, ${ }^{11}$ while the forty thousand black troops who died for the abolitionist cause were largely forgotten (see Franklin 2003). Almost from the moment the war ended public commemorations reconfigured the Civil War as a narrative of white American resistance and sacrifice, a bleached set-piece battle showcasing the glory and generosity of the nation, and most importantly, not a black revolution.

Denuded of the more difficult, contentious, and incomplete narrative of black American liberation, reenactments are for many participants an opportunity to reverence their ancestors, whether the reenactor springs from a Union or Confederate line. 'Ironically', wrote Farmer, the 'phenomenal popularity' of the book and television series Roots, in which Alex Haley traced his lineage back to an ancestor's enslavement in Africa, 'spawned new interest in genealogical research among whites as well as blacks, thus indirectly adding new members to the reenactors' ranks' (Farmer 2005: 58).

Although the overwhelming majority of spectators and participants at reenactments are white, none of the black reenactors whom Kennedy interviewed had ever encountered overt racial insults. On the contrary, black participation gives lie to the outside public's perception of Civil War reenacting as a racist fantasy camp and white reenactors are very much aware of this. As a black reenactor observed, 'We're like celebrities... Even people on the Confederate side always come up to us, and you know, applaud us on what we're doing... And in fact, we turn a lot of people down, because we're invited to so many different events every year' (Kennedy 2004: 15).

By virtue of their own appearance black participants become signs of themselves and their race. As such their appearance alone rehabilitates the narrative told at the event, and increasingly state authority is restructuring performances of the Civil War in order to authenticate their historical role. The National Park Service now schedules civilian reenactors and USCT regiments for Living History presentations, and black reenactors are eligible for grants that cover the cost of reenacting gear, paid by local government agencies (Kennedy 2004: 22).

Excepting this, and the Cook case, authority in authenticity is for reenactors more often a matter of social alliance and exclusion than state policy. Hardcore campaigners explicitly align themselves with the pursuit of genuine authenticity, while leisure-seeking participants expect a more accommodating verisimilitude, informed more by the romance of the Civil War narrative than by extant documentation. As Robert Lee Hodge reminds us, to the authentics the race issue is secondary to this most important division within the reenacting community. 'I want the 
history preserved', said Hodge, 'and I think the Confederacy's a great story about men who did incredible things. But I don't subscribe to a lot of the politics that comes with it'.

Horwitz asked: 'Like what?'

'Like race', answered Hodge. 'I don't give a shit if my sister marries a black guy.

Unless he's a farb' (Horwitz 1996: 246).

\section{Ritual and Reality}

Reenactors' capacity to perform a narrative based on the genuine history of the Civil War is crippled not so much by the participation of some overt racists but by a long-established tendency to isolate black American history from the grand narrative of 'normal' American history. Furthermore Robert Lee Hodge's confession of monomaniacal obsession shows that reenacting is not just a matter of performing a vapid fable of tragically thwarted racial triumph. According to Victor Turner's concept of breach, crisis, and reconciliation, Civil War reenacting ritualizes a generalized and powerful but controlled narrative of resistance.

A Vietnam Veteran and Confederate reenactor told Handler and Saxton of a significant moment he had on the field of a recreated Civil War battle. In the confusion of simulated war, through the smoke and the branches of the trees, all he could see was 'the enemy flag' coming toward him. In his effort to inhabit the personality of an 1860 s Confederate, the impulse to regard the United States flag as an 'enemy' banner stirred up a recollection of the reenactor's real-life wartime experience in the service of the same flag. It created 'a double emotion', an ambivalent sense of loyalty, demanding 'allegiance to the Confederacy as well as to the United States' (Handler and Saxton 1988: 246).

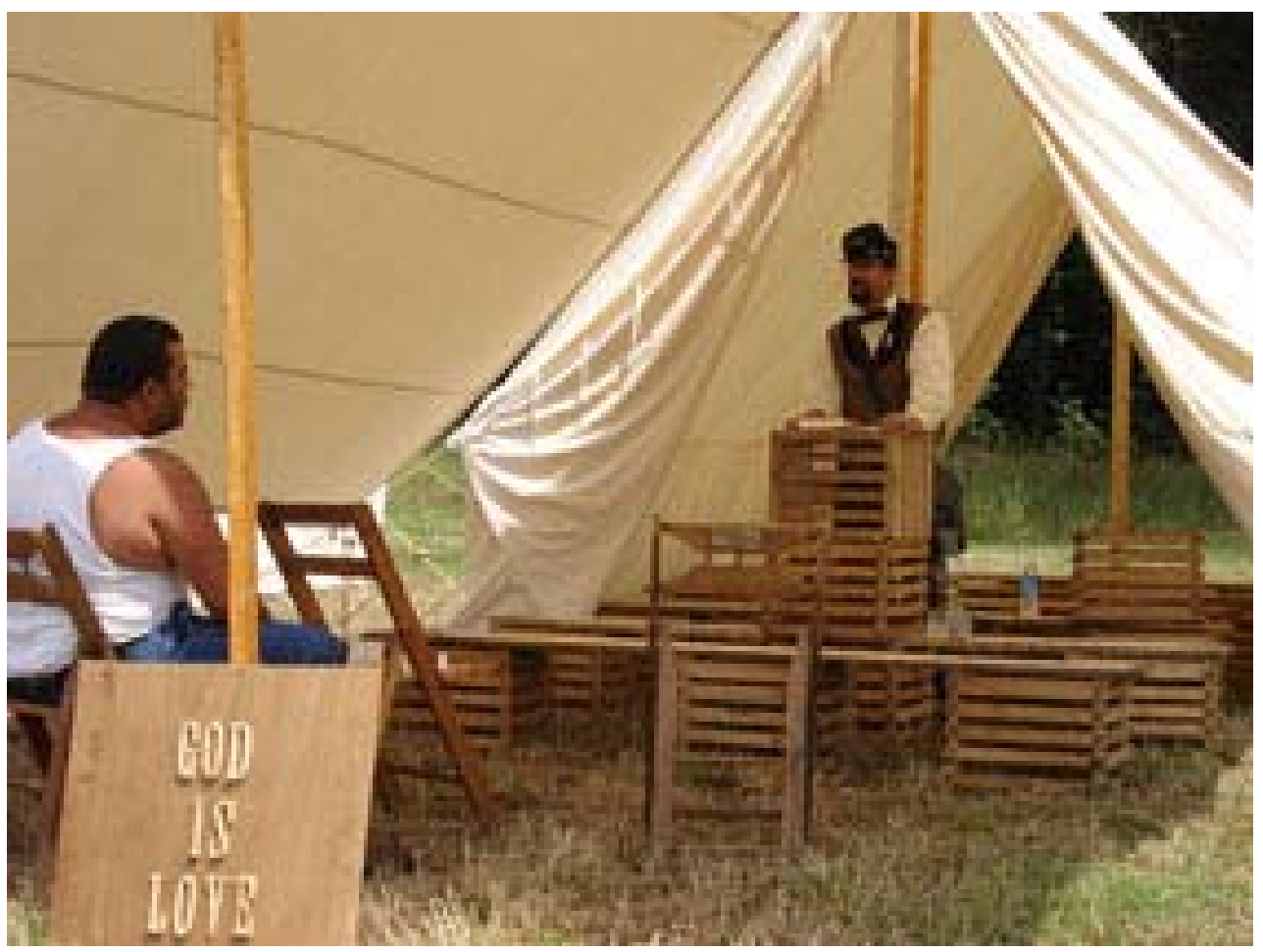

Fig. 9 Period sermon 
When told from a Southern perspective, with death substituted symbolically for defeat and post-war white reconciliation taken as a given, the Civil War narrative illuminates the Christian theme of martyrdom and resurrection. The personal faith of both grey-clad crusaders and the Bible-thumping abolitionists of the 1860s, which they attested to repeatedly throughout their own writings, brings Christianity into the foreground of this narrative. Some reenactors even band together in Christian groups which are modeled on Civil War-era religious associations.

The United States Christian Commission, for instance, was a charitable organization founded by YMCA volunteers to ameliorate the general suffering wrought by the Civil War. ${ }^{12}$ Largely dormant after 1865, twenty-first-century Christians resurrected the Christian Commission

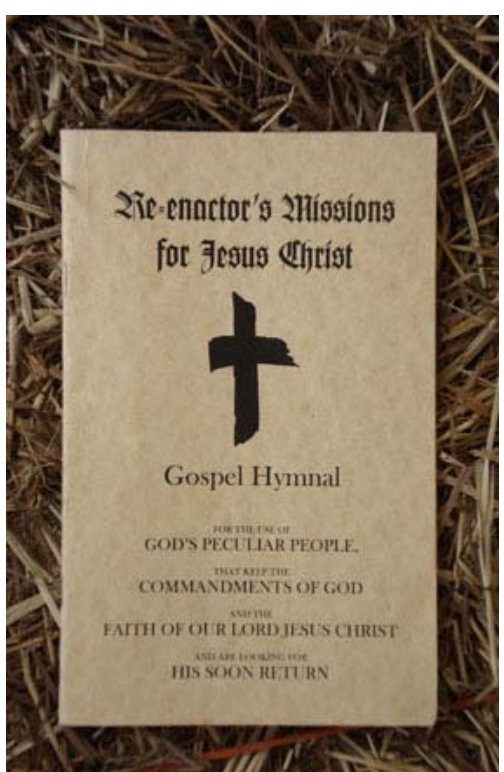

Fig. 10 Hymnal cover listing patriotic anthems as a civilian reenacting group. The grounds they claimed in the Living History Village at Gettysburg, in 2006, featured a canvas tent where a reenactor gave a period sermon. He alluded to 1860s events in the present tense, bemoaning a 'country torn apart by war' and pleading for reconciliation (Fig. 9).

Over at the Activities Tent another reenactor preacher and young couple in period gear staged a mock wedding. As at the Christian Commission the preacher spoke in first-person, as if actually officiating the rite in the 1860s, but he followed his service with a Question and Answer session. First he fielded a question about the relationship between Presbyterian and Congregationalist sects in antebellum America. Over the tent's electronic public-address system the clergyman then asked, "Is there anything else I can answer for you or help you with?' Queried on the potential for conflict between his reenactor role and his role as a modern-day ordained minister, the reverend replied that when doing an impression of a Civil War army chaplain, he made a strict distinction between his 'real' self and his reenacting persona. In the group prayers he led at reenactments, 'a lot of guys ask me to say something about troops coming up from Winchester, up the hill, or something [in-character] like that, but I don't-I have strong opinions on that'.

The loudspeakers at Gettysburg also advertised a 'period worship service' to follow the last scheduled battle. Expecting either a total immersion performance as at the Christian Commission, or a scripted educational scene like the period wedding, I attended. After a man representing himself as the Confederate General Pickett sang 'Silver Bells' in falsetto, a bluff evangelist in loosely authentic civilian costume took the pulpit. Introducing himself as Reverend Farley, he led the congregation in the Pledge of Allegiance. He then led us in singing equally anachronistic patriotic anthems from a hymnal (Fig. 10), and orated on the fury of God's judgment. Drawing a comparison with the degenerate Judeans described in a Bible passage, Reverend Farley sermonized on the subject of material comfort and spiritual poverty, a theme a preacher might propound in 1860,1960 , or 2006. Reverend Farley went on to preach that, like the Biblical Judeans, we are all deceived by our own 'self-sufficiency'. 'We're balancing the budget', he declared. 'Our soldiers enlarge our borders, and yet we do not think of God'.

It gradually became clear to me that Reverend Farley was actually talking about the present-day-or some version of it. Hurricane Katrina was 'not a coincidence', said Farley. He thundered about abortion. He castigated 'those who remove the Ten Commandments from our schools and courtrooms' and 'those who call homosexuality an alternative lifestyle'. Railing against 'formal church-goers', and warning against paying Christianity meaningless lip-service, Farley insisted that 'God wants reality-not ritual! Reality!' And this did indeed seem a peculiar thing for a man in old-fashioned woolens to announce at a Civil War reenactment.

Judging from the appreciative reactions of Farley's congregation, the martyrdom 
mystique of Civil War remembrance seemed to me to veer from bourgeois Sir Walter Scott-style Arthurian chivalric nostalgia toward more current, political territory, particularly the powerlessness and entitlement lately proclaimed in America in the name of the 'angry white male'. The original Civil War required the angry white men of the 1860s to each take stock of his individual commitment to God and his individual commitment to the social order; they pondered Providence and the perseverance of their most dearly held ideals. Reenactors today wonder about their own place in history, and they too hope for the future. The decisions that their 1860s antecedents made on the same issues, however, were all as important as the government itself, as real as corpses stacked in trenches, and as enduring as marble monuments.

Horwitz wrote of an evening at a reenactment of the Battle of the Wilderness, when as he wandered the Confederate camp he happened to overhear the incongruous noise of a Long Island accent. Horwitz followed the sound and discovered a whole crew of New Yorkers: modern-day farmers, factory workers, even whalers-all clad in grey. Their unofficial spokesman was a railroad conductor who harangued Horwitz: 'We play Confederate because we don't like one group of people trying to rule over another', he said. 'It's not the US we're rebelling against, it's the black-hearted businessmen who want to lord it over the working man'. Indicating his neoConfederate New Yorker comrades, he added, 'We've been squeezed, laid-off, down-sized, put down. We're fighting for our freedom, on and off this battlefield' (Horwitz 1996: 137).

If the Civil War was a battle to determine the character of the settlement of the American West, then the Union win imputed to political progressives the authorship of modern, industrialized American life. Today, throughout as much of the North and West as the South itself, the Confederacy is a hot commodity. It is a token for a more parochial patriotism, and for rallying romantic resistance against an effete 'Establishment'.

Often reenactors associate development, or industrial and commercial 'progress', with the immoral agenda of present-day 'progressives'. Their purported lack of appreciation for the importance of Civil War remembrance, as a result of their 'politically correct' contempt for the Confederacy, must be responsible on some level for littering an otherwise unchanged vista with power-lines and asphalt and graffiti, and obliterating the sacred groves where armies camped, generals plotted, and beloved icons expired.

If the ennobled dead are wincing, somewhere, at the destruction of their old stomping

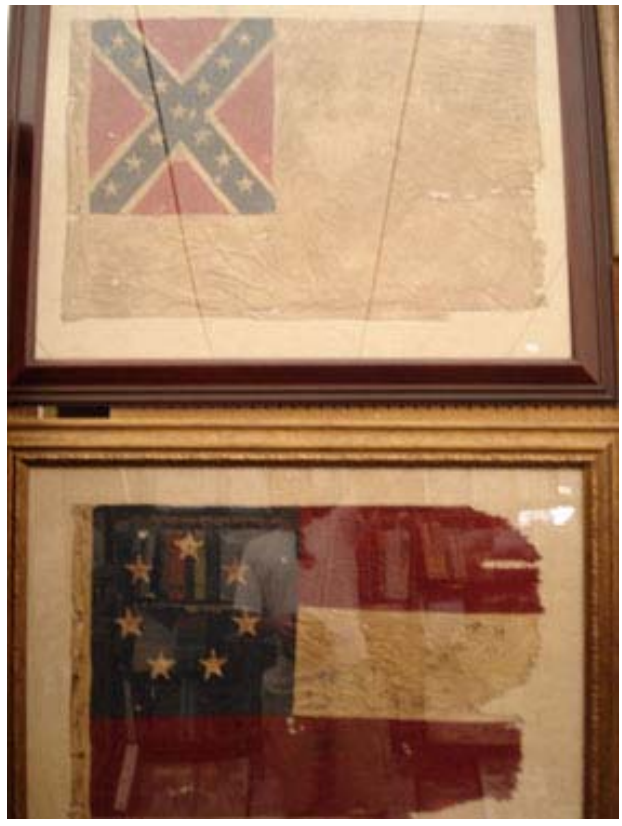

Fig. 11 Replica Confederate flags grounds, then they must find some solace in the fact that they live on as emblems on neoConfederate key-chains and t-shirts. This culture of 'the Confederacy as hood ornament' (Horwitz 1996: 288) has its place in Civil War reenacting-specifically, on 'Sulter's Row'. Also termed 'The Mall' in reenacting parlance, this is a section at large mainstream events where vendors hawk the haversacks, replica rifles and wool coats essential to a reenactor's impression, as well as assorted t-shirts and tchotchkes.

Plastic swords and period wooden dice games were on offer for children, and for adults there were antique gun parts and framed Civil War-themed prints. I had to stop when I spotted tattered Confederate flags mounted, framed, and on sale for $\$ 500$ (Fig. 11). As I photographed the replicas, a yokel behind me blurted out: 'Hey! I bet that flag's been around a long time huh?' This suggested to me that perhaps someone that day had actually bought these charred, twenty-first-century Confederate dwarf pennants in the mistaken belief that their aged appearance-and the extortionate price itself-signalled authenticity. 
Hadden remembered the early 1970s when 'Antiques were still fairly cheap... and this was an interesting but short-lived period when reproductions were often more expensive than the originals' (Hadden 1996: 4). The old sabres and brass badges once heaped in junk stores and neglected attics now fetch thousands of dollars on their way to mantelpieces and museum cases, while in the meantime a competitive market has emerged for producing new replica goods that have been out of use for as much as a hundred years. Civil War reenactors themselves are

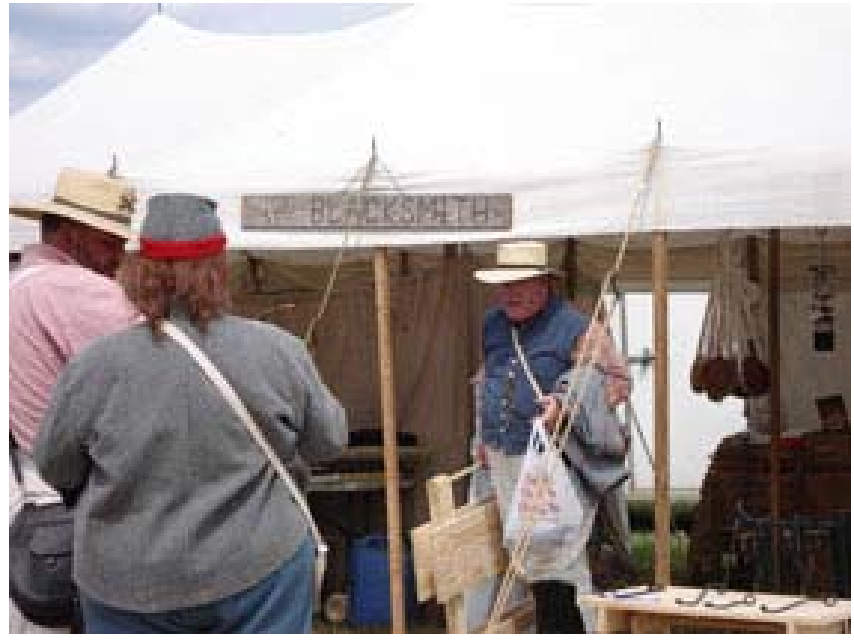

Fig. 12 Shopping for the authentic tilting at Appadurai's (1986) 'tournament of value', where rather than the simple math of supply and demand, connoisseurship and the fetishization of particular commodities negotiates price and availability (Appadurai 1986: 19). Furthermore any visitor to the Gettysburg area or any historic site in the South will notice the profusion of heritage-themed business names, such as Gettysburg's own ‘Battlefield Harley-Davidson' dealership. ${ }^{13}$

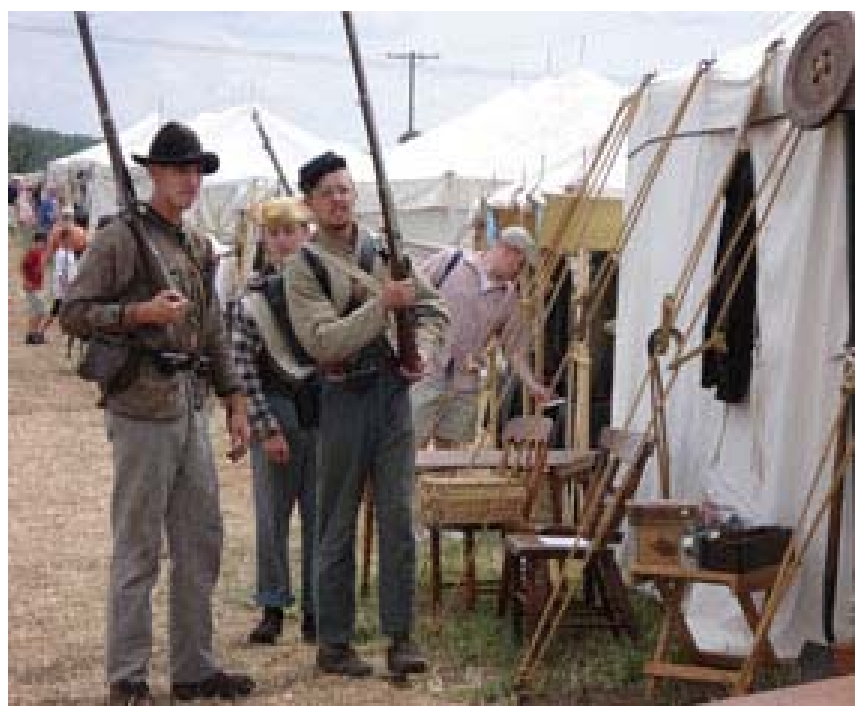

Fig. 13 Shopping for the authentic

Casualties in this tournament are the actual Civil War archaeological sites. Aside from the threat of trolley lines and modernday developers' bulldozers, metal-detector-wielding 'safari' diggers-few of them reenactors, but some of them 'sutlers'-now sweep historic locations unearthing original 1860s gear to collect privately or sell. Sometimes they dig protected areas illegally, but lately the managers for historic sites like Fort Powhatan, Virginia, have organized their own relichunting tours. Fort Powhatan's program is called 'Diggin' in Virginia' while the 'Grand National Relic Shootout' is another (Shulte 2006).

Many booths at Gettysburg proffered authentic spent Civil War ammunition, one of the most common finds for relic-hunters. Meanwhile spectators and reenactors alike approached the booths on The Mall as if they were on a shopping spree (Figs. $12 \& 13$ ), and the impulse to own the authentic item -a thing imbued, in the context of Civil War remembrance, with spiritual value- has created a cottage-industry feeding-frenzy. The potential for the acquisitive mores of consumer culture to interfere with an authentic appearance prompted a commentator at Reenactor.net to warn against over-provisioning for a Civil War impression, ${ }^{14}$ and a Union 
reenactor at the Battle of New Market ridiculed the farbs who have 'four guns stuck in here [gestures to waistband] and knives, and big hats' (Turner 1990: 127).

On the Gettysburg reenactment's busy Mall, the 'Sons of Confederate Veterans' (SCV) pitched a big tent, too (Fig. 14). Prominently displayed was a hotline, 1-800-MY-DIXIE, that concerned neo-Confederates could call to report a 'heritage violation'. Parents of high school students, for example, might make a case for a 'heritage violation' if their children have been prevented from wearing Confederate insignia to school.

The SCV's hotline actually connects the caller to an affiliated Georgia organization called the 'Heritage Preservation Association' (HPA). One of many Dixie-themed activist groups that spread, as Horwitz put it, 'like kudzu' across the South during the mid-90s, it flourished on the evasively racist rhetoric deployed to meet the NAACP's protests against flying rebel battle flags from atop government buildings. The HPA operates a PAC for channeling funds to sympathetic political candidates. Horwitz (1996) interviewed the HPA's founder, Lee Collins, who remarked, 'The heritage movement is a brand-new industry... It's like Lotus was ten years ago, producing spread sheets while others produced software. Now, Lotus will sell you a database. We've created a niche, too. A niche of the civil rights industry' (Horwitz 1996: 289).

A South Carolina chapter of the SCV now hosts its own annual reenactment, and it is claimed that a portion of the proceeds from the event furnish for local schools new history textbooks that emphasize pride in 'Southern heritage' (Farmer 2005: 67). The SCV, however, are hardly the only ones eager to turn a hobby into an industry. 'Recognizing the appeal of reenacting, corporations, chambers of commerce and tourism departments now routinely sponsor Civil War events', said Virginia Business Online's Rob Morano. 'In the past', added Morano, Civil War reenactors tended to be 'colorful blue-collar types', but 'Now, executives and professionals are joining the fray... [and] there's a chance your boss-even your boss's boss-may be a weekend warrior as well'. ${ }^{15}$

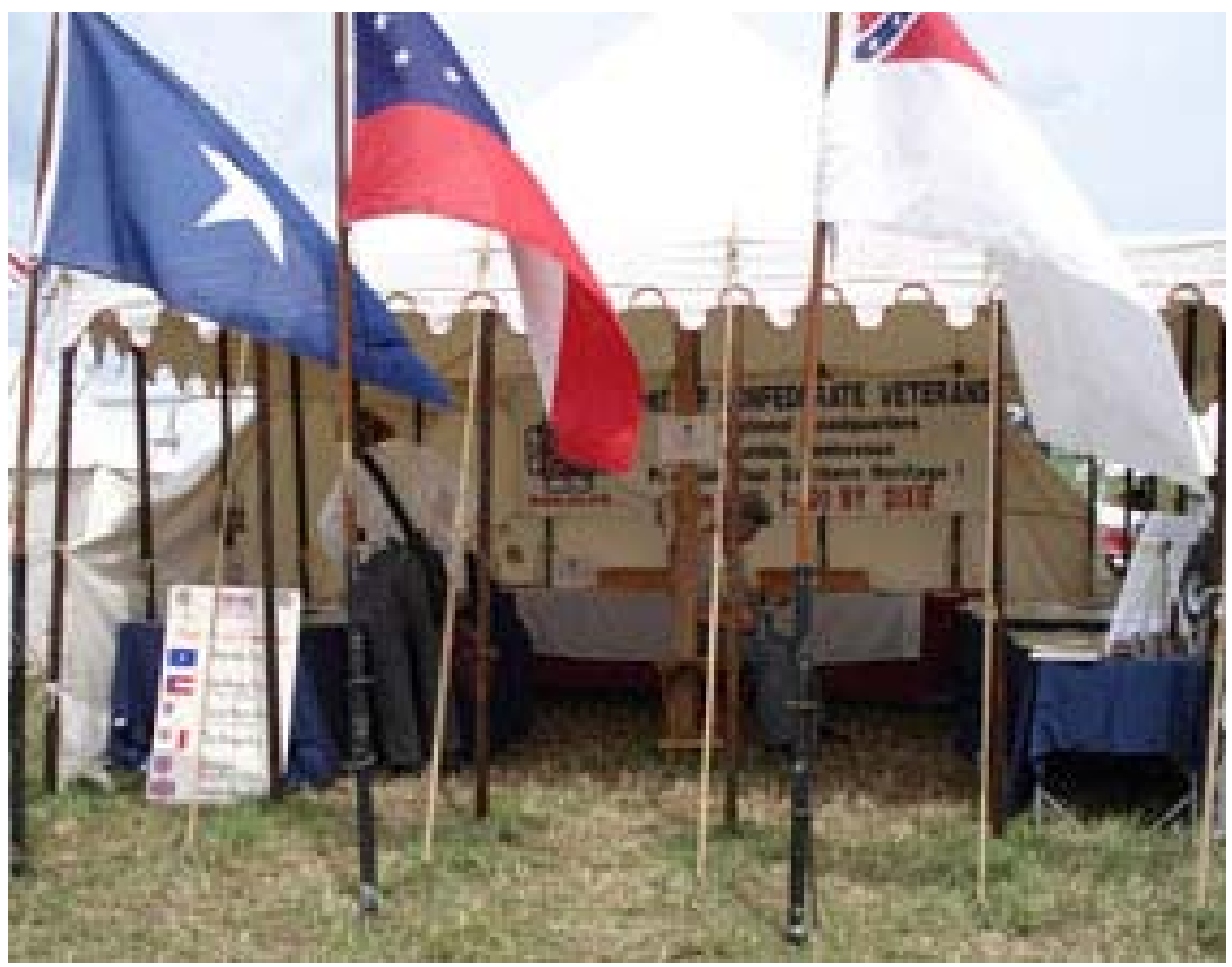

Fig. 14 'Sons of Confederate Veterans' tent 


\section{Conclusion}

'Creative nostalgia reveals the fantasies of the age', wrote Svetlana Boym (2001: 352). She also noticed that 'Culture is increasingly squeezed between the entertainment industry and religion, while education is understood more and more as management and therapy' (Boym 2001: 351). If this compression of culture leaves any room for Living History, then I hope there is room for Robert Lee Hodge and other reenactors to collect donations for green spaces and historic homes; and a place for Private Brandon to camp out, orate on the manufacture of denim in the 1860s, describe Civil War tactics or indeed discuss anything else that his voluminous knowledge of the past can possibly offer to anyone who will listen.

The serious study of history, however, must amount to something more than the mere ability to rattle off a collection of technical facts, and if reenactment generally falls short of this then it should be remembered that so too does some scholarship. In fact the connection between reenactment and historical scholarship has been shown to be, at least in the case of Cook's publication of They Fought like Demons, a fruitful contribution to the body of knowledge that deals with the American Civil War. Furthermore reflexive anthropological scholarship treats the study of ritual as a ritual in itself, and authenticity arouses the Civil War enthusiasts in the woods of Pennsylvania and Virginia as much as it guides the tenured Civil War scholars at universities in the same states. However the postmodernists would have us believe the key difference here is that reenactors, unlike scholars, are not intellectually persuaded to take an interest in the Civil War; their interest is not on the basis of its historical import, and Dr Rowe did not really take up the hobby in order to broaden her role as a mother, a wife, and a doctor, and enrich her twenty-first-century life, but rather to escape it.

Handler and Saxton proclaimed that 'living historians [i.e. reenactors] seek to reexperience history because they expect thereby to gain access to lives and experiences characterized by the wholeness that historical narratives can provide [emphasis in original]' (Handler and Saxton 1988: 251). In other words the 'authentic experience' that reenactors grope for is nothing more than 'the notion that an authentic life is a storied or emplotted life' (Handler and Saxton: 250).

Handler and Saxton were right to draw attention to the central importance of story in Civil War reenactments, but in the sense given by Victor Turner reenactors also inhabit structure and anti-structure, breaking down and rebuilding the authoritative narrative. Though some event organizers have staged reenactments of Union victories where rebels win instead (Horwitz 1996: 135), reenacting authentically-that is to say, leaving Union victories as Union victories, at the very least-invokes the genuine narrative, the historically documented progress of events as sanctioned by authority. Wavering, always, in his or her immersion into a period character, through this reflexive process the reenactor communicates with his or her Civil War self only by virtue of his or her present-day role as the omniscient narrator, who knows-even obsesses over knowing-exactly when the Battle of Gettysburg began; exactly where General Hancock rallied the First Minnesota; exactly when the Confederate attack faltered; exactly where Abraham Lincoln died. Civil War reenactors pick over these small details, dwelling on buttons and hats and movements and locations, so that the whole performance scintillates with a wealth of verifiably genuine facts, while leaving unresolved the main question posed by the war itself-that is, Who is more American? Confederate or Unionist?

Contradicting Handler and Saxton's post-modernist contention that Civil War reenacting is a trap that simulates the original events even as it obliterates their true meaning, Bruner established the fact that the ascendance of 'hyperreality' over reality is not unique to recent history but rather an aspect of the human experience that is as old and inescapable as ritual itself. 'We all enter society in the middle', he wrote, 'and culture is always in process'. In his analysis the 'original' 1830 s New Salem was itself a copy of 1820 s villages, in that 1820 s American villages were adapted, modified, and 'subject to whatever creative modifications were devised by the [1830s] New Salem residents' (Bruner 1994: 407). The 1820s villages were each in turn recreations of still more previous ways of building and settling, so that the tourists' twentyfirst-century version of New Salem is but the latest village to emerge from a long-running heritage of replication by conscious approximation. 


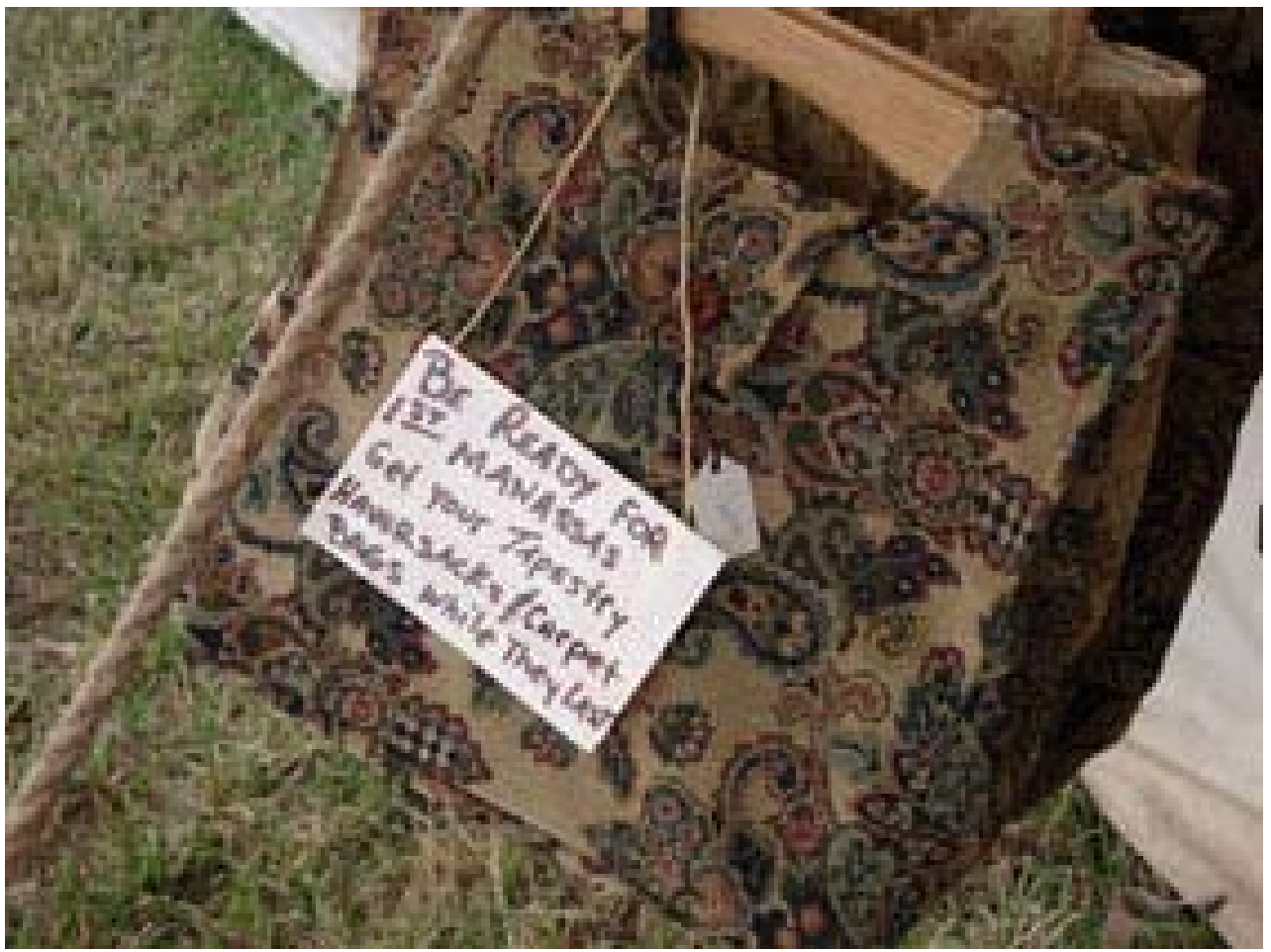

Fig. 15 Label of a hand-made carpet-bag

In the 'hyperreality' of ritual replication, though, does a conscious approximation of the original sometimes give way to an unconscious approximation-and if authenticity is a discourse that does not depend on personal belief or commitment to remain dominant, does it matter whether it is one or the other? Is there in fact something of the myopia and fanaticism of an antebellum pro-slave fire-eater in the Reverend Farley, for instance? And when neo-Confederate heritage activists pontificate on 'civil rights' and Long Island-born rebels unironically express their dislike of 'one group of people trying to rule over another', surely it approximates the hypocrisy of the original Confederates, who clamored for state sovereignty, for the right to selfdetermination, and their freedom-to own others as slaves?

Thinking, too, about the Zouaves, with their fondness for North African costumes, and the giddy delight of carpet-bag-toting Washingtonian civilians on their way to witness the Battle of First Manassas, I was struck by the ways in which reenactment participants, and even observers, seem at times to approximate-unconsciously, rather than consciously-the activities and intents of the original actors. A testament to the ongoing overlap of leisure and war, for instance, appeared to me on the label of a hand-made carpet-bag offered for sale on The Mall at Gettysburg 2006 (Fig. 15).

Rejecting the postmodern take on Civil War reenactment permits a more meaningful understanding of the subject because Civil War reenacting is not only a 'good way to learn about the past' in the sense that a reenactment digests the power of the original Civil War event by approximating it, and then conveying something of this power to the audience by way of representation; it is also a good way to learn about the legacy of racial oppression in the United States, as well as the strategies of resistance and alterity that have shaped American national identity over more than a hundred years of history, and it could also be a good way to learn about the changing social roles of women since the nineteenth century. Furthermore it is an excellent way to learn how intensely and immediately the presence of the past is felt in the lives of Americans today. 
In any exhibitionary context it is by approximating the original as closely as possible that genuine authenticity is achieved. Usually the challenges that curators or designers or heritage site interpreters face in this task are great. Yet American Civil War reenactment shows how a strange kind of layered authenticity can appear where mimetically graduated virtualities enfold the realities of the past, and rather than being attributable to some forlorn consumer psychology, as idealized by postmodernists, it is instead the fascinating power of the Civil War story itself that draws hundreds of thousands of Americans to reenactments, and it is on the basis of its continuing relevance to American society that so many modern Confederates seem to be not just over-enthusiastic participants, but genuinely possessed by the past.

Received $5^{\text {th }}$ April 2007

Finally accepted $17^{\text {th }}$ July 2007

\section{Notes}

1 Photographs taken by the author with permission.

2 McPherson, J. (2003) Transcript of speech given in support of the Gettysburg National Battlefield Museum Foundation, <http://www.gettysburgfoundation.org/whoweare-8.2.htm> accessed 1 September, 2006

3 Trammell, J. (2004) 'Fight for battlefield preservation goes on', http://www.washingtontimes.com/civilwar/20041126-085505-5919r.htm accessed 1 September, 2006

4 Marcus, A. (2002) 'When Janie Came Marching Home', http://www.aosoc.org/Webmistress_Choices/WhenJanieCameMarchingHome.htm accessed 21 August, 2006

5 University of Texas at Austin (1997) 'News of the American Medical Equestrian Association', http://tarlton.law.utexas.edudawson/amea/may97nws.htm accessed 16 August, 2006

6 Clark, Wes (2006) 'The Reenactor's Movie Guide', http://wesclark.com/jw/movie2.html, accessed 24 August, 2006

7 Carson, B. and Sue Rhodes (2006) 'Tips For Beginning A Civilian Role', http://www.shasta.com/suesgoodco/newcivilians/advice/role.htm accessed 17 August, 2006

8 Barth, J. (1996) 'The Red Badge of Make Believe Courage',

http://outside.away.com/outside/magazine/0396/9603fred.html accessed 17 August, 2006

9 (2006) Stonewall Brigade Homepage, http://www.stonewallbrigade.com/ accessed 21 August, 2006

10 (2006) 'The Fighting 54th Today', http://www.awod.com/cwchas/54ma.html\#today accessed 17 August, 2006

11 Georgia Encyclopedia (2006) 'Black Troops in Civil War Georgia', http://www.georgiaencyclopedia.org/nge/ArticlePrintable.jsp?id=h-783 accessed 20 August, 2006

12 Christian History Institute (2002) 'November 16, 1861: Civil War Christian Commission Was Formed', http://chi.gospelcom.net/DAILYF/2002/11/daily-11-16-2002.shtml accessed 3 August, 2006

13 Paddock, S. (2006) 'No Casino Gettysburg', http://www.nocasinogettysburg.com/ accessed 1 September, 2006

14 Bennet, S. (2001) 'Start to Improve Your Impression Today', http://www.reenactor.net/acw/improve_bennett.htm accessed 19 August, 2006 
15 Morano, R. (2002) 'Re-enacting a bloody past', http://www.reenactor.net/acw/improve_bennett.htm accessed 20 August, 2006

\section{References}

Appadurai, A. (1986) 'Introduction: commodities and the politics of value', in A. Appadurai (ed.) The Social Life of Things: Commodities in Cultural Perspective, 3-63, Cambridge: Cambridge University

Baudrillard, Jean (1984) 'The Precession of Simulacra', in Brian Wallis (ed.) Art after Modernism: Rethinking Representation, 253-281, New York: New Museum of Contemporary Art

Boym, S. (2001) The Future of Nostalgia, New York: Basic Books

Bruner, E. (1994) 'Abraham Lincoln as Authentic Reproduction: A Critique of Postmodernism', American Anthropologist, 96 (2) 397-415

Cavin, D. with Megan Cronan, Andrew Kerins, and David Scott (2005) 'Hardcore Leisure: A Source of Division Within Leisure Social Worlds', presented at the 11th Canadian Congress on Leisure Research, Nanaimo, British Columbia, 17-20 May

Cushman, S. (1999) Bloody Promenade: Reflections on a Civil War Battle, Charlottesville: University of Virginia

Dunning, T. (2002) 'Civil War Re-Enactments: Performance as a Cultural Practice', Australasian Journal of American Studies, 63-73

Farmer, J. (2005) 'Playing Rebels: Reenactment as Nostalgia and Defense of the Confederacy in the Battle of Aiken', Southern Cultures, 11(1) 46-72

Franklin, J. (1962) 'A Century of Civil War Observance', The Journal of Negro History 47 (2) 97 107

Hadden, R. (1996) Reliving the Civil War: A Reenactor's Handbook, Mechanicsburg, Pennsylvania: Stackpole Books

Handler, R. and William Saxton (1988) 'Dyssimulation: Reflexivity, Narrative, and the Quest for Authenticity in "Living History"', Cultural Anthropology 3 (3) 242-260

Horwitz, T. (1996) Confederates in the Attic: Dispatches from the Unfinished Civil War, New York: Pantheon

Kauffman, W. (2006) The Civil War in American Culture, Edinburgh: Edinburgh University Press

Kennedy, A. (2004) 'The Social Rules of Engagement: Race and Gender Relations in Civil War Reenactment', Master of Arts Thesis, Ohio State University

Lawson, M. (2002) Patriot Fires: Forging a New American Nationalism in the Civil War North, Lawrence: University Press of Kansas

Schulte, B. (2006) 'Unearthed War Relics See Battle Again', The Washington Post, April 16, A1

Turner, R. (1990) 'Bloodless Battles: The Civil War Reenacted', The Drama Review, 34(4) 123136 
Young, E. (1999) Disarming the Nation: Women's Writing and the American Civil War, Chicago: University of Chicago Press

* Lain Hart holds a BA in War Studies from King's College, London, and recently received an MA in Museum Anthropology from Columbia University in New York City. He is presently enrolled in a post-graduate program at the British Museum, and lives in Bethnal Green.

\section{Address}

email flainh@yahoo.com 